WARSZTATY Z GEOGRAFII TURYZMU

ISBN 978-83-7969-262-0 $\quad$ s. 101-113

http://dx.doi.org/10.18778/7969-262-0.07

Agnieszka NIEZGODA

Uniwersytet Ekonomiczny w Poznaniu

\title{
CZAS WOLNY A ZMIANY NA RYNKU TURYSTYCZNYM
}

\section{Wstęp}

Czas wolny jest kategorią towarzyszącą zmianom ludzkości i procesom jej dynamicznego rozwoju. Zmieniająca się cywilizacja to zmieniający się człowiek i jego otoczenie, ale również to zmieniający się sposób zagospodarowania czasu wolnego (BOMBOL 2008). Czynności wykonywane w czasie wolnym mają odzwierciedlenie $w$ potrzebach konsumpcyjnych. Zróżnicowanie tych potrzeb oraz zróżnicowanie sposobu ich zaspokajania związane jest z postępem technicznym i informacyjnym. Źródłem popytu na zróżnicowane sposoby zagospodarowania czasu wolnego jest chęć człowieka do samorealizacji, ale również do społecznego wyróżniania się. Ta chęć powoduje np. poszukiwanie coraz nowszych sposobów i miejsc wypoczynku, a więc stymuluje rozwój nowych form turystyki i nowych obszarów recepcji turystycznej. Inną podstawową zależnością pomiędzy czasem wolnym a turystyką jest związek czasu wolnego z czasem pracy. Brak czasu wolnego i niedostateczny wypoczynek należą do istotnych przyczyn obniżających wydajność pracy jednostki (BOMBOL 2008). Stąd też wynika zależność pomiędzy czasem wolnym, czasem pracy a funkcją rekreacyjną i regeneracyjną turystyki. Zależności te mają jednak charakter bardziej złożony, ponieważ czas pracy umożliwia osiąganie dochodów, które mogą być przeznaczane na zagospodarowanie czasu wolnego, w tym na konsumpcję dóbr i usług turystycznych. 
Istnienie czasu wolnego uważa się za niezbędny warunek uczestnictwa $\mathrm{w}$ ruchu turystycznym. Zależności pomiędzy czasem wolnym a turystyką można jednak analizować szerzej. Wynika to z faktu zmieniającej się struktury czasu i jego podziałów, odejścia od tzw. synchronizacji, czyli zacierania różnic pomiędzy czasem pracy a czasem wolnym oraz tzw. kompresji czasu. Celem opracowania jest analiza roli czasu wolnego w przemianach charakteryzujących zjawisko turystyki (współczesnej i w przyszłości).

Udział w ruchu turystycznym jest zjawiskiem coraz bardziej powszechnym, a turystyka zaczyna pełnić coraz więcej funkcji, co związane jest również z pojawianiem się nowych form i rodzajów turystyki. Typy aktywności turystów zależą od wielu czynników, takich jak wiek, pozycja społeczna i materialna jednostki, wykształcenie czy miejsce zamieszkania. Sposób spędzania czasu wolnego jest zatem silnie warunkowany społecznym, cywilizacyjnym i ekonomicznym otoczeniem jednostki (BOMBOL 2005). Poprzez zmiany czasu wolnego można analizować zmiany w turystyce.

\section{Czas wolny - istota i definicja}

Na postrzeganie czasu, jego mierzenie oraz podziały na różne kategorie, w tym na czas pracy i czas wolny, wpłynęły przeobrażenia cywilizacyjne, a przede wszystkim rozwój gospodarki kapitalistycznej. O ile chałupniczy system pracy pozwalał na dobrowolność w ustalaniu, kiedy czas poświęcony jest na pracę, o tyle system kapitalistyczny zmuszał robotników najemnych do przestrzegania punktualności, z uwagi na odgórne ustalanie godzin pracy. Nastąpiła zmiana oceny czasu wolnego, T. Veblen uważał go za wyznacznik tzw. klasy próżniaczej, natomiast etyka purytańska klasyfikuje „trwonienie czasu jako występek" (WHITROW 2004). Kapitalistyczny system pracy zmusił do wyraźnego podziału między czasem pracy a czasem wolnym. Dało to podstawy rozwoju turystyki zorganizowanej. W wyniku procesów społecznych w XIX w. pojawiły się prawne gwarancje do czasu wolnego. Tradycja pewnych zachowań i rytuałów z nim związanych jest więc silnie zakorzeniona i osadzona w świadomości społeczeństwa XXI w. (BOMBOL 2008).

Zagadnienie czasu wolnego jest problemem złożonym. Wpływa no to proces zmian w postrzeganiu czasu. $W$ ujęciu historycznym czas postrzegany jest jako czas cykliczny, rozumiany jako nawracające, powtarzalne okresy w życiu ludzkim, wzorowane na powracającym cyklu życia przyrody. W społe- 
czeństwie nowoczesnym czas postrzegany jest jako czas linearny, odzwierciedlony $\mathrm{w}$ przeżywaniu chwili obecnej oraz zwracaniu się ku przyszłości (szerzej: WHITROW 2004). Takie postrzeganie związane jest $\mathrm{z}$ implikacjami dotyczącymi konieczności świadomego przeżywania i wykorzystania czasu, a także poczucia konieczności jego oszczędzania. Czas wolny jest zatem kategorią społecznie i kulturowo zmienną. Jest wytworem społeczeństwa przemysłowego i zmienia się wraz z jego przekształceniami (MYŚLIWSKA 2011).

Sposoby ujmowania czasu wolnego można podzielić na (BOMBOL 2008):

1. Klasyczne (wzorowane na filozofii starożytnej). Czas wolny, podobnie jak kontemplacja, jest wyższym stanem ludzkiego bytu, wyzwala zdolność wznoszenia się ponad zwykłe, szare życie, pozwala na samorealizację oraz odnalezienie sił życiowych pozwalających znosić wszystko to, co wynika z konieczności podejmowania pracy.

2. Społeczne (za prekursora tego podejścia uważa się T. Veblena). Czas wolny obejmuje całokształt życia człowieka poza pracą, a jego ilość pozostająca $w$ dyspozycji jednostki jest niczym innym jak wskaźnikiem jego przynależności do określonej klasy społecznej.

3. Kładące nacisk na obligatoryjność czynności i zachowań. Czas wolny jest czasem jednostki uwolnionym od pracy oraz rodzajów aktywności z pracą związanych (dojazdy, nauka, poprawa umiejętności, relacje ze współpracownikami). Dotyczy to czynności związanych z zaspokojeniem potrzeb egzystencjalnych (sen, higiena, posiłki). Wszelkie czynności, w których pojawia się jakakolwiek obligatoryjność wykonania, należy uznać za czas częściowo wolny semi-leisure.

4. Związane ze stanem ducha i umysłu (koncepcja holistyczna). Czas wolny to bycie zaangażowanym w czynności wykonywane dla nas samych, które prowadzą nas do osiągania przyjemności i satysfakcji, które zbliżają nas do sensu istnienia. Czas wolny to czas bycia sobą, wyrażania talentów i umiejętności.

5. Czas wolny rozumiany jako przeciwieństwo pracy.

6. Czas wolny jest najczęściej definiowany w opozycji do czasu pracy jako sfera przyjemności, dobrowolności i bezinteresowności. Przyjęcie powyższego sposobu definiowania czasu wolnego oznacza, że nie można skonstruować listy czynności, które ten czas zajmują (MYŚLIWSKA 2011).

Czas wolny określany jest również poprzez funkcje, jakie ma do spełnienia dla jednostki i społeczeństwa. Do podstawowych funkcji czasu wolnego zalicza się: 
- reprodukcję sił człowieka (odnowę sił fizycznych);

- rozrywkę (regenerację sił psychicznych);

- rozwój kulturalny (rozwój osobowości, kwalifikacji, wiedzy).

Kwestia zdobywania kwalifikacji i wiedzy jest sporna, niektórzy autorzy uważają, że wykonywanie czynności, które w jakikolwiek sposób związane są z pracą zawodową wyklucza przynależność czasu wykonywania tych czynności do kategorii czasu wolnego. Jako podstawową można przyjąć definicję sformułowaną przez E. WNUKA-LIPIŃSKIEGO (1972), który czas wolny określa jako: „czas pozostający do osobistej dyspozycji człowieka po spełnieniu przez niego obowiązków zawodowych, rodzinnych, szkolnych oraz zaspokojeniu potrzeb biologicznych organizmu".

Reasumując można przyjąć, że czas wolny jest kategorią czasu poza pracą zawodową, pozostającą do swobodnej decyzji, zgodnej z zainteresowaniami, a wykorzystywanej na wypoczynek, rozwijanie zainteresowań, uczestniczenie w zdobyczach cywilizacji, imprezach kulturalnych, poświęconą na rozrywkę itp. (GOŁEMBSKI, NIEZGODA 2012). Czas wolny może być także przeznaczony na podnoszenie kwalifikacji zawodowych poprzez samokształcenie i tym samym wpływać na wzrost wykorzystania czasu pracy. Czas wolny nie oznacza już indywidualnego i społecznego lenistwa czy marnotrawstwa, lecz ze względu na swoje funkcje stał się potencjalnym źródłem powiększania zasobów kapitału ludzkiego i społecznego, które są ekonomicznie pożądane. $W$ podejściu ściśle ekonomicznym czas wolny uważany jest za dobro zbyt rzadkie $\mathrm{w}$ stosunku do zapotrzebowania na nie, a więc także posiada swą użyteczność nadawaną w procesie konsumpcji. Już Petrarka zauważył, że: „,z czasem jest jak ze wszystkim innym. Im czegoś pozostaje mniej, tym to coś staje się bardziej cenne" (WHITROW 2004). Czas wolny może być zatem traktowany obiektywnie - $\mathrm{w}$ minutach, godzinach, dniach itp., oraz subiektywnie - jako czas przyjemności, relaksu, odpoczynku, czas wolny od jakiejkolwiek konieczności (BOMBOL 2008).

Współczesna cywilizacja prowadzi do zwiększania zasobów czasu wolnego w układzie dobowym, rocznym oraz związanym z całym życiem człowieka. Powoduje to, że czas wolny może być przeznaczany nie tylko na prostą regenerację sił fizycznych, ale na coraz bardziej ciekawe i nowe formy jego spędzania. Czas wolny staje się zatem czasem przeznaczonym na konsumpcję coraz bardziej różnorodnych dóbr i usług. Wśród nich bardzo ważne miejsce zajmują usługi turystyczne. 


\section{Usługi turystyczne a układ rynkowy dla czasu wolnego}

Naturalną domeną czasu wolnego jest sfera indywidualna, ponieważ w tym wymiarze realizują się trzy główne atrybuty czasu wolnego: dowolność, dobrowolność i dyskrecjonalność (CZAJA 2011). Dla rozważań dotyczących konsumpcji, rozumianej jako proces zaspokajania potrzeb, istotne znaczenie ma wolność wyboru człowieka co do czynności, które będzie wykonywał w czasie wolnym. Konsument bowiem osiąga satysfakcję dzięki posiadaniu i zagospodarowywaniu czasu wolnego. W odniesieniu do możliwości zaku$\mathrm{pu}$ dóbr i usług konsumowanych $\mathrm{w}$ związku $\mathrm{z}$ istnieniem czasu wolnego w literaturze spotyka się określenie „rynki czasu wolnego”. Jak zauważają G. CIELOCH, J. KUCZYŃSKI i K. ROGOZIŃSKI (1992), nie można mówić o jednolitym układzie rynkowym dla czasu wolnego. Istnieją bowiem trzy układy, w jakie wchodzi czas wolny, a mianowicie: rynek na czas wolny, rynek czasu wolnego i rynek dla czasu wolnego.

Przez „rynek na czas wolny” należy rozumieć rynek, w którym celem transakcji jest posiadanie (wygospodarowywanie) i sprzedaż czasu wolnego. Produktem jest czas wolny, a mechanizmowi rynkowemu towarzyszy czasooszczędna orientacja konsumentów, którzy poszukują dóbr pomagających zaoszczędzić czas. „Rynek czasu wolnego” pojawia się wtedy, gdy konsumenci poszukują produktów i usług umożliwiających wykorzystanie i spędzenie czasu wolnego. "Rynki dla czasu wolnego" obejmują splot rynków cząstkowych, do których zalicza się: rynek usług kulturalnych, rekreacyjnych, świadczonych przez mass media, a także usług turystycznych i gastronomicznych. Są to tzw. rynki czasochłonne, które charakteryzują się dużą substytucyjnością. Dla rynków tych charakterystyczną cechą jest wyjątkowe zindywidualizowanie potrzeb klienta. W literaturze podkreśla się, że wymienione rodzaje rynków związanych z czasem wolnym należy analizować nie tylko przez pryzmat elementów składowych, ale kolejności ich występowania. Oznacza to, że w trakcie rozwoju społeczno-gospodarczego pojawia się najpierw rynek na czas wolny, a dopiero później rynek czasu wolnego oraz rynek dla czasu wolnego (CIELOCH, KUCZYŃSKI, ROGOZIŃSKI 1992, CZAJA 2011, BOMBOL 2008).

Turystyka zaliczana jest do rynków dla czasu wolnego. Uznaje się przede wszystkim fakt, że jej celem jest „zagospodarowanie czasu wolnego”, ma więc charakter czasochłonny. Nie można jednak ograniczać swojego spojrzenia, ponieważ z drugiej strony zauważalne jest dążenie do oszczędzania czasu poprzez korzystanie z konkretnych usług turystycznych. Dotyczy to 
przede wszystkim rozwoju transportu. Jak zauważa G. WHITROW (2004), przejawem wzrastającej roli czasu $\mathrm{w}$ rozwoju społecznym jest zorganizowany system transportu. Dążenie do zaoszczędzenia czasu spowodowało rozwój środków transportu, nie tylko w sferze zwiększania ich szybkości, ale w zakresie ich zróżnicowania. Różnorodne możliwości sposobów podróżowania powodują, że sama podróż może być atrakcją. Przykładem może być korzystanie $z$ niezwykle drogiego pociągu Orient Expres. W sytuacji korzystania z niezwykle atrakcyjnego środka transportu klienci mogą chcieć wydłużać podróż i usługa transportowa zamiast „czasooszczędna” może stać się „czasochłonna”. Z kolei przykładem oszczędzania czasu jest korzystanie z nowoczesnych systemów rezerwacyjnych. Skrócenie czasu jest też charakterystyczne dla wielu usług gastronomicznych czy informacyjnych. Można zatem stwierdzić, że turystyka jako zjawisko społeczne ma na celu zagospodarowanie czasu wolnego, co powoduje, że jest klasyfikowana do rynków dla czasu wolnego. Jednak rozwój cywilizacyjny powoduje, że usługi cząstkowe wchodzące w skład produktu turystycznego często mają na celu zaoszczędzenie czasu. Relacja czasu wolnego do turystyki łączy zatem w sobie dwie kwestie, a mianowicie: czasu wolnego jako warunku koniecznego do partycypacji w ofercie turystycznej oraz braku czasu wolnego, stymulującego rozwój oferty oszczędzającej czas.

\section{Wpływ czasu wolnego na zmiany w usługach turystycznych}

Sposób spędzania czasu wolnego jest silnie uwarunkowany społecznym, cywilizacyjnym i ekonomicznym otoczeniem jednostki. Według T. Veblena czas wolny był wyróżnikiem klasy próżniaczej i wskazywał na status danej osoby. Obecnie również, niezależnie od zasobów posiadanego czasu, istotne jest jego zagospodarowanie w sposób prestiżowy i pokazowy. Czas wolny i sposoby jego zagospodarowania stały się nośnikami informacji o sytuacji materialnej jednostki (BOMBOL 2008). Zjawiskiem decydującym o postrzeganiu i wykorzystywaniu czasu wolnego jest ewolucja społeczeństw w kierunku tzw. cywilizacji czasu wolnego (leisure civilization). To zjawisko spowodowane jest zmianami w indywidualnych systemach wartości zachodzących pod wpływem środków masowego przekazu, a także w wyniku tzw. stresów cywilizacyjnych i coraz silniej odczuwanej potrzeby relaksu, zmiany aktywności, zdobywania doświadczeń, chęci poznawania nowych ludzi, miejsc itp. 
Badając zmiany w turystyce, zauważalne stają się coraz nowsze potrzeby i wymagania osób biorących udział w ruchu turystycznym. Wzrost poziomu zabezpieczenia materialnego prowadzi do coraz większego znaczenia wartości indywidualnej jakości życia, w tym czasu wolnego rozumianego jako wyróżnik tej jakości. Wynika to też z faktu skrócenia czasu pracy oraz coraz większych oczekiwań w stosunku do spełnienia i samorealizacji w życiu człowieka poprzez wykorzystanie czasu wolnego. Współcześni turyści chcą się wyróżnić poprzez korzystanie z niezwykłych i niepowtarzalnych form wypoczynku, nie chcą "marnować wakacji” często zapominając, że właśnie wypoczynek może polegać na spokojnym spędzaniu czasu.

Ważną kwestią staje się zatem maksymalizacja użyteczności czasu wolnego. Czas wolny staje się dla jednostki cennym zasobem, ponieważ daje satysfakcje $\mathrm{i}$ jest oceniany poprzez dystans do czasu pracy. W warunkach względnego dobrobytu konsumentów z krajów OECD jedną z barier wzrostu konsumpcji w tych krajach jest nie tyle brak siły nabywczej, co czasu na niektóre formy spożycia, co prowadzi ze strony konsumentów do wyboru czasooszczędnych form aktywności. W długim okresie raczej deficyt czasu niż zasobów pieniężnych staje się jednym z podstawowych problemów dojrzałych gospodarek (JUNG 2011). Ilość zasobów czasu wolnego może wpływać na cenę usług turystycznych, ponieważ cechują się one przewidywaną przez konsumenta użytecznością. Dlatego można mówić o cenie czasu.

Wyższym dochodom towarzyszy zazwyczaj wyższa wartość czasu. Inaczej zachowują się konsumenci, których wartość czasu jest niska i są skłonni przeznaczyć więcej czasu na poszukiwanie tańszych produktów bądź usług. W praktyce oznacza to, że osoby, dla których czas ma wyższą wartość, skłonne są zapłacić pośrednikowi za zorganizowanie wyjazdu turystycznego, natomiast osoby o niższych dochodach, skłonne są poświęcić swój czas na organizację ruchu turystycznego, oszczędzając przy tym marżę pośrednika (NIEZGODA, ZMYŚLONY 2003). Świadomość wartości ograniczonych zasobów czasu wolnego skłania ludzi do poszukiwania coraz większej satysfakcji zeń płynącej, co w turystyce może przejawiać się skłonnością do poszukiwania coraz to nowych form wypoczynku, różnorodnych niepowtarzalnych usług i miejsc niezwykłych, nieodwiedzanych przez innych turystów.

Współcześni turyści chcą „efektywnie” wykorzystywać czas. Oznacza to, że w czasie wyjazdu chca jak najwięcej przeżyć i doświadczyć. Ludzie dążą do maksymalizacji doświadczeń na jednostkę czasu. Z konieczności szybkiego wyboru wielu doświadczeń wynika tzw. "zachowanie kameleona” 
(NIEZGODA 2010b). W czasie jednej podróży turysta może odgrywać wiele ról, korzystać np. z bardzo taniego noclegu i bardzo drogiego środka transportu, oszczędzać na jedzeniu i jednocześnie kupować bardzo drogie ubrania itp. W związku z tym w zakresie podaży turystycznej można zauważyć przejście od "gospodarki zorientowanej na usługi" (service-oriented economy) do "gospodarki zorientowanej na przeżycia” (experience-oriented economy) (NIEZGODA 2010a). Analizując postępowanie klienta zauważalna jest również orientacja na najbardziej sprzyjającą lub przyjemną ofertę, z rozluźnieniem społecznych obowiązków i rutynowych zachowań, co prowadzi do zmniejszenia lojalności klienta. Współczesny turysta będzie poszukiwał zatem coraz to nowych miejsc, nowych atrakcji, nowych sposobów spędzania czasu, a dodatkowo będzie chciał jak najwięcej atrakcji „,umieścić" w czasie jednego urlopu.

W przypadku osób „zasobnych" w czas wolny szczególną rolę może odgrywać kwestia oderwania się od szarej rzeczywistości dnia codziennego i uatrakcyjnienia pojemnych ilościowo własnych zasobów czasu wolnego (BOMBOL 2008). Zatem te osoby też będą chciały zagospodarować czas wolny w sposób jak najbardziej niezwykły i ciekawy. Tym bardziej, że jeśli ten zasób jest duży, nie będą one poszukiwać oszczędności czasu. Odzwierciedleniem takiej oceny czasu w turystyce jest przejście od „podróżnika” do "turysty" (MEHMETOGLU 2004). Podróżnik to człowiek pracujący nad czymś, dla którego podróż jest pewnym procesem i środkiem do większych celów, turysta natomiast poszukuje przyjemności, nowych doświadczeń i przygody. Turysta w sposób pasywny oczekuje wydarzeń i obsługi. Podróżnik aktywnie działa i nie chce być obsługiwany (NIEZGODA 2010a). We współczesnej turystyce zauważalne są obydwa sposoby podróży. $Z$ jednej strony turyści korzystają chętnie z gotowych pakietów charakterystycznych dla turystyki masowej, z drugiej strony zauważalna jest moda na niepowtarzalny sposób podróży, a nawet przerwa w obowiązkach życiowych, która przeznaczana jest na długą podróż bez udziału organizatora turystycznego (tzw. gap year).

Stosunek ludzi do współczesnych przeobrażeń związanych z czasem wolnym najlepiej oddaje określenie „kurczący się czas i przestrzen””. Oznacza ono postępujące obniżanie rangi przestrzeni publicznej i niwelowanie odległości czasowych. Zjawisko to nazywane jest również „kompresją czasu i przestrzeni" i rozumiane jest jako zmiana atrybutów współczesnego życia, co wyraża się intensyfikacją produkcji i konsumpcji w jednostce czasu (CZAJA 2011). Czas traci swój wymiar, komunikacja (najszerzej rozumiana) 
wymaga coraz mniej czasu. Przestrzeń przestaje się liczyć tak jak dawniej, odległości znaczą coraz mniej. Elity dzisiejszego świata, ale też turyści są coraz mniej związani z konkretnym terytorium, coraz bardziej niezależni od ograniczonych przestrzeni społeczno-kulturowych i politycznych, stając się w tym sensie eksterytorialni (GOŁEMBSKI, NIEZGODA 2012). W przypadku konsumenta kompresja czasu wyraża się $\mathrm{w}$ intensyfikacji produkcji i konsumpcji czy obu tych czynności naraz w jednostce czasu. W celu zaoszczędzenia czasu współcześni konsumenci wykonują kilka czynności jednocześnie lub starają się zminimalizować czas tych czynności.

Współcześni turyści wymagają szerokiego wachlarza możliwości zaspokojenia potrzeb, jednocześnie chcą błyskawicznego dostępu do informacji, rezerwacji i szybkiego dokonania wyboru. Procesy globalizacji oraz związany z nimi rozwój komunikacji wraz z szerokim dostępem do Internetu powodują łatwość poszukiwania oferty oraz rezerwacji na własną rękę.

Na współczesnym rynku, w tym rynku turystycznym, pojawia się kategoria aktywnych konsumentów nazywanych prosumentami. Aktywność konsumenta na rynku może dotyczyć zarówno współdziałania konsumenta i producenta w procesie tworzenia dóbr i usług, jak też może dotyczyć tworzenia sieci innych konsumentów, pełnienia funkcji liderów opinii itp. (NIEZGODA 2013). Sieci konsumentów umożliwiają wykorzystanie cudzych doświadczeń i uniezależnienie się od informacji przekazywanych przez przedsiębiorstwo. Turyści zamieszczają $\mathrm{w}$ sieci informacje o warunkach pobytu w hotelu, o miejscowościach, obsłudze przez konkretnego organizatora turystycznego. Wymiana informacji dzięki Internetowi jest szybka, a konsumenci zaoszczędzają czas potrzebny do uzyskania wiedzy na temat planowanej podróży.

Poszukiwanie oferty na własną rękę skutkuje coraz większym znaczeniem Internetu $\mathrm{w}$ promocji regionu. Obserwacja zachowań nabywców $\mathrm{w}$ tym gotowości do korzystania z sieci (e-readiness) - skłania agencje do coraz większego nasilenia aktywności internetowej. Według badań obejmujących polską branżę biur podróży, 99\% przedsiębiorstw turystycznych wykorzystuje Internet w swojej codziennej działalności (KACHNIEWSKA, NAWROCKA, NIEZGODA, PAWLICZ 2012). O wyborze zakupów w formie on line decyduje czas ich dokonywania, ale również wygoda, szeroki asortyment produktów i możliwość ich porównywania, a także cena, która w Internecie może być niższa (BOMBOL 2008). Współczesny konsument na rynku turystycznym poszukuje takich form dystrybucji, które pozwolą zaoszczędzić czas, dlatego cenna jest błyskawiczna wymiana informacji. Z drugiej strony 
analizy wykorzystania Internetu wskazują, że konsumenci coraz więcej czasu spędzają korzystając $z$ tego środka przekazu. Rynek mass mediów jest jednym z rynków dla czasu wolnego, dlatego można uznać, że są to usługi zarówno czasochłonne, jak też czasooszczędne.

Aktywność konsumenta w kreowaniu produktu na własny użytek wynika z faktu, że dysponuje on ograniczoną ilością czasu wolnego i chce w jak największym stopniu wykorzystać ten czas (BYLOK 2012). Pojawia się zatem proces zacierania granic pomiędzy czasem wolnym a czasem pracy. A. ToFFLER (2001) wiąże to zjawisko ze skutkami tzw. trzeciej fali i nazywa odejściem od „synchronizacji". Skutkiem tych procesów na rynku turystycznym jest łączenie aktywności zawodowej z wypoczynkiem, przez co zaciera się różnica między czasem wolnym i czasem pracy (KACHNIEWSKA, NAWROCKA, NiEZGODA, PAWLICZ 2012). Przykładem takiej sytuacji jest korzystanie z usług rekreacyjnych $\mathrm{w}$ czasie trwania konferencji lub zwiedzanie miasta, w którym odbywają się targi lub kongres. Innym przykładem odejścia od synchronizacji jest wykonywanie obowiązków zawodowych w czasie trwania urlopu, co jest możliwe dzięki nowoczesnym technologiom (telefony komórkowe, dostęp do Internetu). Następstwem odejścia od synchronizacji jest "planowana spontaniczność”, która polega na zacieraniu różnic pomiędzy działaniami prywatnymi, spontanicznymi, na pozór bezinteresownymi a działaniami nastawionymi na korzyść. Konsumenci zamieszczają w sieci informacje o swoim pobycie, wakacjach itp., a w zamian oczekują od innych polecenia miejsc godnych uwagi (gdzie zjeść, nocować, co robić w czasie wolnym itp.). Konsumenci stają się prosumentami, a czas wakacji nie do końca jest czasem wolnym.

\section{Podsumowanie}

Spełniając wiele różnorodnych funkcji, czas wolny wpływa na style konsumpcji. Funkcje czasu wolnego podlegają silnym oddziaływaniom socjokulturowym oraz ze strony procesów globalizacji i relacji międzykulturowych (CZAJA 2011). Za pomocą coraz nowocześniejszych środków masowego przekazu, z Internetem na czele, kreowane są nowe potrzeby, które z kolei napędzają globalny popyt. Stąd też wzmożona konsumpcja, która cechuje społeczeństwo tzw. cywilizacji zachodniej, powoduje, że działalność człowieka, którą wpisać można w definicję czasu biologicznego oraz ekono- 
micznego, nieustannie się wydłuża. Okres starszego wieku jest najdłuższym etapem w życiu konsumenta (NIEZGODA, JERZYK 2013). W turystyce zauważa się coraz większe znaczenie segmentu osób starszych jako nabywców usług turystycznych. Należy też pamiętać, że są to osoby doświadczone, które przyzwyczajone są do podróży turystycznych. Zatem ich wymagania co do jakości usług mogą być wysokie.

Zmiany, jakie następują w strukturze czasu, a przede wszystkim zwiększenie zasobów czasu wolnego, sprawiają, że można spodziewać się wzrostu ruchu turystycznego. Poszukując nowych sposobów "zagospodarowania” czasu wolnego ludzie poszukiwać będą coraz to nowych miejsc i sposobów wypoczynku. Sprzyja to rozwojowi nowych form turystyki. Z drugiej strony tzw. kompresja czasu, przejawiająca się dążeniem do wykonywania wielu czynności w coraz krótszym czasie, powoduje, że współczesny turysta będzie dążył do maksymalnego wykorzystania czasu urlopu. W zakresie podaży turystycznej zjawiska te wywołują konieczność przygotowania oferty interesującej, niezwykłej, a przede wszystkim bogatej w różnorodne usługi i atrakcje. Trend do „duchowego przeżywania” urlopu oraz wysoka ocena wartości czasu mogą z kolei spowodować chęć wyróżnienia się i spędzania urlopu w roli "podróżnika" a nie "turysty”, nastawionego na obsługę i zaliczanie atrakcji. Jednak do takiego zachowania konieczne jest zabezpieczenie $\mathrm{w}$ środki materialne, czyli praca wymagająca wykorzystania czasu w opozycji do czasu wolnego. Zatem powstaje tzw. deficyt czasu wolnego odzwierciedlony w wysokiej ocenie użyteczności czasu.

Innym ważnym zjawiskiem będącym efektem opisywanej przez A. Tofflera "trzeciej fali” jest zacieranie różnic pomiędzy czasem pracy a czasem wolnym. Znajduje to również odzwierciedlenie w turystyce, ponieważ wiele osób podróżując nie musi rezygnować z obowiązków zawodowych dzięki współczesnym technologiom. Poza tym często czas podróży nie zostaje oddzielony od obowiązków służbowych (spotkania, interesy).

Reasumując rozważania na temat czasu wolnego i zmian na rynku turystycznym można stwierdzić, że współczesne przemiany charakteryzujące podejście i ocenę czasu wolnego znajdują odzwierciedlenie $w$ zachowaniu turystów, co wymaga przygotowania oferty i właściwej struktury produktu turystycznego. Czas wolny nie jest tylko prostym warunkiem uprawiania turystyki, jego wpływ dotyczy różnych zmian w zakresie popytu i podaży turystycznej. 


\section{BIBLIOGRAFIA}

BOMBOL M., 2005, Ekonomiczny wymiar czasu wolnego, Szkoła Główna Handlowa w Warszawie, Warszawa.

BOMBOL M., 2008, Czas wolny jako kategoria diagnostyczna procesów rozwoju społeczno-gospodarczego, Szkoła Główna Handlowa w Warszawie, Warszawa.

BYLOK F., 2012, Między ulegtościq a suwerennościq konsumenckq - zmiany w relacjach producent-konsument na rynku XXI wieku, [w:] G. Rosa, A. Smalec (red.), Marketing przysztości. Trendy. Strategie. Instrumenty, "Zeszyty Naukowe Uniwersytetu Szczecińskiego", 711, s. 341-356.

CIELOCH G., KUCZYŃSKI J., ROGOZIŃSKI K., 1992, Czas wolny czasem konsumpcji, PWE, Warszawa.

CZAJA S., 2011, Czas w ekonomii, Wyd. Uniwersytetu Ekonomicznego we Wrocławiu, Wrocław.

GoŁembSKi G., NiEZGodA A., 2012, The Role of Time in the Global Tourism Market - A Demand Perspective, [w:] M. Kasimoglu (ed.), Visions for Global Tourism Industry, InTech, Rijeka, s. 167-178.

JUNG B., 2011, W kierunku nowej ekonomii czasu wolnego, [w:] R. Winiarski (red.), Rekreacja i czas wolny. Studia humanistyczne, Oficyna Wydawnicza Łośgraf, Warszawa, s. 160-174.

KACHNIEWSKA M., NAWROCKA E., NIEZGODA A., PAWLICZ A., 2012, Rynek turystyczny, Wolters Kluwer, Warszawa.

MeHMETOGLU M., 2004, Tourist or Traveller? A Typological Approach, AIEST, „Tourism Review”, 59, 3, s. 33-39.

MYŚLIWSKA K., 2011, Socjologia czasu wolnego, [w:] R. Winiarski (red.), Rekreacja i czas wolny. Studia humanistyczne, Oficyna Wydawnicza Łośgraf, Warszawa, s. 134-159.

NiEZGODA A., 2013, Prosumers in the tourism market: the characteristic and determinants of their behaviour, „Poznan University of Economics Review”, 13, 4, s. 130-141.

NIEZGODA A., JERZYK E., 2013, Seniorzy w przyszłości na przykładzie rynku turystycznego, [w:] G. Rosa, A. Smalec (red.), Marketing przysztości. Trendy. Strategie. Instrumenty, „Zeszyty Naukowe Uniwersytetu Szczecińskiego", 777, s. 475-490.

NiEZGODA A., 2010a, Nowe trendy w popycie - wyzwanie dla obszarów recepcji turystycznej, [w:] S. Tanaś (red.), Nauka i dydaktyka w turystyce i rekreacji, Łódzkie Towarzystwo Naukowe, Łódź, s. 21-34.

NiEZGODA A., 2010b, Marketing doznan - nowe narzędzie czy nierozłączny element turystyki, [w:] M. Kazimierczak (red.), Wspótczesne podróże kulturowe, AWF, Poznań, s. 121-131.

NiEZGODA A., ZMYŚLONY P., 2003, Popyt turystyczny - uwarunkowania i perspektywy rozwoju, Wyd. Akademii Ekonomicznej w Poznaniu, Poznań.

TOFFLER A., 2001, Trzecia fala, Państwowy Instytut Wydawniczy, Warszawa.

WHITROW G.J., 2004, Czas w dziejach, Prószyński i S-ka, Warszawa.

WNUK-LIPIŃSKI E., 1972, Praca i wypoczynek w budżecie czasu, Ossolineum, Wrocław.

\section{LEISURE TIME AND CHANGES ON THE TOURIST MARKET}

Key words: leisure time, tourist market

\section{Summary}

Leisure time is a prerequisite for participation in tourism. However, the impact of leisure time on the tourist services market is much bigger. Namely, it affects primarily consumer behaviour which reflects changes in the perception, importance, price and division of leisure time. This article's goal is to analyse the role of leisure time (in a demand-related approach) in determining tourism (present 
and in the future). Consideration on free time and its perception in the society are concluded with a projection of future tourism services.

The main changes in tourism caused by changes of leisure are: a transformation from serviceoriented economy to experience-oriented economy, compression of time and space, withdrawal from synchronization resulting from the so-called "third wave", departure from a traditionally construed idealistic "traveller" towards the notion of the "tourist", chameleon behaviour and prosumers form as a category of consumers in the tourist market. The article is of a theoretical nature with studies of literature on the subject as the adopted research method. 